10. Domashnie nasylstvo v Ukraini : skilky v kraini zhertv $i$ shcho zahrozhuie kryvdnykam [Domestic violence in Ukraine: how many victims in the country and what threatens offenders]. Available at: https://ukr.segodnya.ua/ ukraine/domashnee-nasilie-v-ukraine-ktostanovitsyazhertvami-i-chto-grozit-obidchikam1099013.html [in Ukrainian].

11. Kulyk, L. M. (2009). Oznaky nasylnytskoi zlochynnosti [Signs of violent crime]. State and Regions: Law Series, no.2. pp. 65-69. [in Ukrainian].

12. Stepanenko, O. V. (2018). Systematychnist yak oznaka domashnoho nasylstva [Systematics as a sign of domestic violence]. Odesa, pp. 204-206. [in Ukrainian].

13. Fromm, E. (1990). Myssyia Zyhmunda Freida.
Analyz eho lychnosty y vlyianyia $=$ Sigmund Freuds Mission. An Analysis of His Personality and Influence [Sigmund Freud's mission. Analysis of his personality and influence $=$ Sigmund Freud's Mission]. Moscov, $1990.144 \mathrm{p}$. ISBN 5-7777-0002-0. [in Russian].

14. Sharhorodska, S. (2007). Nasyllia v simi : vydy, naslidky, shliakhy podolannia [Domestic violence: types, consequences, ways to overcome]. Social pedagogue. No. 2.pp. 14-16. [in Ukrainian].

15. Iurkiv, Ya. I. (2013). Nasylstvo ditei u simi yak sotsialno-pedahohichna problema [Violence of children in the family as a socio-pedagogical problem]. Scientific Bulletin of Uzhgorod University: Series: Pedagogy. Social work. Uzhhorod, 2013. Vol. 28. pp. 185-189. [in Ukrainian].

Стаття надійшла до редакції 27.04.2021

УДК 378.091.3:373.5.011.3-051]:78

DOI:

Чжоу Сіньюй, аспірант кафедри педагогіки мистеитвва та фортепіанного виконавства Національного педагогічного університету імені М.П. Драгоманова

\title{
ПРИНЦИП ОПОРИ НА ЄВРОПЕЙСЬКИЙ МУЗИЧНО-ІСТОРИЧНИЙ ДОСВІД У ФОРМУВАННІ ПОЛІФОНІЧНОГО СЛУХУ СТУДЕНТІВ 3 КНР У ПРОЦЕСІ ФОРТЕПІАННОГО НАВЧАННЯ
}

У статті актуалізовано проблему формування поліфонічного слуху студентів з КНР у процесі фортепіанного навчання. Здійснено огляд сучасних наукових робіт китайських авторів з метою обтрунтування доцільності запропонованого принщииу. Виявлено, щуо означений принцип розглядався авторами в інших проєкиіях з підкресленням взаємодії культур. Виявлено ознаки європейського музично-історичного досвіду та його вплив на формування майбутнього вчителя музичного мистецтва. Запропоновано педагогічні умови, створення яких уможливить реалізацію зазначеного принцину. Акиентовано увагу на необхідності розвитку поліфонічного мислення студентів, а також на опануванні прийомів виконання поліфонії різних епох, стилів і жанрів.

Ключові слова: музично-історичний досвід; поліфонічне мислення; фортепіанне навчання; начіональні традииї музичної освіти; майбутній вчитель музичного мистеитвва.

Jim. 6.

Zhou Xinyu, Postgraduate Student of the Pedagogy of Art and Piano Performance Department Mykhaylo Drahomanov National Pedagogical University

\section{THE PRINCIPLE OF RELIANCE ON EUROPEAN MUSIC-HISTORICAL EXPERIENCE IN THE FORMATION OF CHINESE STUDENTS' POLYPHONIC HEARING IN THE PROCESS OF PIANO LEANING}

The article actualizes the problem of forming polyphonic hearing of Chinese students in the process of piano learning. The author carries out the review of modern scientific works of Chinese authors to substantiate the feasibility of the proposed principle. It was found that young Chinese researchers who studied the system of Ukrainian music and pedagogical education (Wing Bin, Wang Ying Yun, Lan Xijun, Ding Yun, Fu Xiaojing, Hou Yue, Chen Kai, Shuguang) pay attention to the prospects of studying the views of famous European musicians for modern musical education and the formation of pianistic experience. In their research, they highlight the most important principles and methods of teaching for Chinese music pedagogy; and apply time-tested forms of organization of executive activity. The importance of national and world orientation of piano teacher training in music is emphasized.

The signs of European music-historical experience in the context of the formation of polyphonic hearing are revealed: awareness of the importance of previously unknown musical knowledge, methods, and techniques of polyphonic technique; the possibility of applying the acquired knowledge and skills in their own musical performance; correspondence of polyphonic thinking to stylistic features of musical works.

Pedagogical conditions are proposed, the creation of which will enable the implementation of this principle. Emphasis is placed on the need to develop the students' polyphonic thinking, as well as on mastering the techniques of performing polyphony of different eras, styles, and genres.

(C) Ч. Сіньюй, 2021 


\section{ПРИНЦИП ОПОРИ НА ЄВРОПЕЙСЬКИЙ МУЗИЧНО-ІСТОРИЧНИЙ ДОСВІД У ФОРМУВАННІ}

ПОЛІФОНІЧНОГО СЛУХУ СТУДЕНТІВ 3 КНР У ПРОЦЕСІ ФОРТЕПІАННОГО НАВЧАННЯ

It was found that in piano lessons future music teachers: systematically master the polyphonic structure of musical works through the understanding of objective musical-historical processes; acquire erudition in the art of music of different types, styles, genres, etc. ; learn to navigate in the historical conditionality of musical styles and genres; realize and learn to apply the principles of organization of musical language during analytical and interpretive activities; improve their own understanding of the musical logic of formation and its compliance with the content; master the skills of verbal interpretation.

Keywords: music-historical experience; polyphonic thinking; piano teaching; national traditions of music education; future teacher of music art.

П остановка проблеми. Оволодіння різноманітними методами і прийомами розвитку виконавської поліфонічної техніки стає необхідною умовою ефективності майбутньої професійної діяльності педагогамузиканта. Їх полівекторність у процесі фортепіанного навчання пояснюється як специфікою музичного інструмента, так і особливостями музичної підготовки студентів. Варто зазначити, що усе розмаїття методів для формування поліфонічного мислення i, зокрема, для розвитку поліфонічного слуху необхідно використовувати не ізольовано, а в різних сполученнях, що дає змогу активно розвивати усі музичні здібності, а також формувати музичні інтереси та художні смаки.

Формування поліфонічного слуху студентів у процесі фортепіанного навчання має застосовуватися як на загальнонаукових, такі спеціальних принципах, орієнтування на які може якісно розвинути їх слухові орієнтири, а також удосконалювати процес і результат навчальної діяльності.

У педагогіці мистецтва, поряд із основними дидактичними принципами, такими як: доступність, емоційність, наочність навчання, міцність засвоєння знань, умінь і навичок, індивідуальний підхід до учнів, зв' язок навчання 3 життям, науковість, систематичність й послідовність тощо, для підготовки фахівців музичної освіти розробляються специфічні, властиві саме цій галузі знань, принципи.

Мета статті - обгрунтувати принцип опори на європейський музично-історичний досвід як основу формування поліфонічного слуху студентів 3 КНР в процесі фортепіанного навчання.

Аналіз основних досліджень та публікацій. Обгрунтовуючи доцільність застосування музичноісторичного досвіду у навчальному процесі музично-педагогічних закладів освіти, також зауважимо, що особлива цінність такого досвіду $\epsilon$ важливою для фортепіанної підготовки китайських студентів, адже вони на попередніх етапах свого навчання практично не мали можливостей ознайомитися 3 виконавськими традиціями видатних музикантів (Ф. Бузоні, Г.Гульда, М.Лонг, А. Рубінштейна, Г. Соколова, А. Шнабеля та ін.) й музично-педагогічними установками Н. Голубовської, Й. Гофмана, К. Ігумнова,
О. Гольденвейзера, Г. Нейгауза, Л. Оборіна, С. Савшинського, Я. Флієра, А. Щапова та ін.) минулих часів. Виконавський і педагогічний досвід кожного з цих музикантів є унікальним, оскільки презентує непересічні культурні цінності й розвиває музичне мислення виконавців. Тому знайомство 3 ним вимагає вивчення i впровадження у навчальний процес фортепіанної підготовки студентів упродовж всього навчання у педагогічному університеті.

Виклад основного матеріалу. Названі постаті в своїй роботі звертали пильну увагу на важливість розвитку поліфонічного мислення у студентів-піаністів. До сьогоднішнього дня залишаються актуальними такі їх методичні поради: граючи на роялі, необхідно намагатися найбільш яскраво відтіняти, висвітлювати окремі елементи звукових конструкцій. Зокрема Л. Оборін зазначав: "Не можна допускати, щоб учень чув тільки верхній голос, а усі останні змішував у однотонний, аморфний звуковий потік”. Подібні думки висловлювали Л. Баренбойм, Ф. Блюменфельд і К. Ігумнов. Вони постійно добивалися від своїх вихованців вслуховування у всі елементи звукової тканини. Гармонія в іiі різному фактурному викладі, поліфонія з окремими підголосками, фортепіанна інструментовка і регістровка - усі ці взаємозв'язані елементи музики сприяють створенню художнього образу в усій повноті й багатоплановості.

Підкреслимо, що й молоді китайські дослідники, які вивчали систему української музично-педагогічної освіти (Він Бін, Ван Інзюнь, Лань Сіцзюнь, Дін Юнь, Фу Сяоцзін, Хоу Юэ, Чень Кай, Шугуан та ін.) звертають увагу на перспективність вивчення поглядів відомих європейських музикантів для сучасного музичного навчання і формування піаністичного досвіду. У своїх дослідженнях вони виокремлюють найбільш значущі для китайської музичної педагогіки принципи і методи навчання, застосовують вже перевірені часом форми організації виконавської діяльності тощо. Наприклад, дослідниця

Фу Сяоцзін переконливо доводить, що фортепіанна підготовка вчителя музичного мистецтва має характеризуватися не тільки національною, а й світовою спрямованістю. При 


\section{ПРИНЦИП ОПОРИ НА ЄВРОПЕЙСЬКИЙ МУЗИЧНО-ІСТОРИЧНИЙ ДОСВІД У ФОРМУВАНН ПОЛІФОНІЧНОГО СЛУХУ СТУДЕНТІВ 3 КНР У ПРОЦЕСІ ФОРТЕПАНННОГО НАВЧАННЯ}

цьому авторка спирається на принципи китайської філософії “хуасі” й “сіхуа”, тому що вони, зберігаючи свої національні особливості, забезпечують процес сприйняття іншої культури. У навчальному процесі це проявляється через прагнення китайських студентів, майбутніх учителів музичного мистецтва навчитися мислити “по-європейськи”, а саме: засвоювати європейську музичну мову під час вивчення класичної музики різних жанрів та стилів $[5,7]$. У роботі автор наголошує, що фортепіанну підготовку китайських студентів в Україні необхідно здійснювати з позицій “діалогу культур”, оскільки він допомагає набути відповідного досвіду.

Подібні думки знаходимо у дослідженні Шугуана. Автор пропонує під час підготовки вчителя музичного мистецтва враховувати сучасні тенденції розвитку обох країн (України Китаю). 3 одного боку, орієнтуватися на національні традиції в культурі та музичній освіті Китаю, а 3 іншого - сприймати національні традиції європейських країн та музичної освіти України. В результаті Шугуан робить висновок, що фортепіанне навчання китайських студентів у системі музично-педагогічної освіти України забезпечується двома паралельними напрямами. В одному відбувається опора на європейські музичні традиції фортепіанного навчання, в другому - фортепіанна підготовка враховує особливості педагогічної діяльності вчителя музики [6].

До найважливіших ознак такого досвіду можемо віднести такі:

- новизна (усвідомлення важливості для власного фортепіанного виконавства раніше невідомих музичних знань, методів і прийомів поліфонічної техніки);

- актуальність (можливість застосування набутих знань у власній музично-виконавській діяльності);

- результативність (відповідність поліфонічного мислення стильовим особливостям музичних творів).

Важливою, на нашу думку, є опора на знання та уміння, отримані студентами в процесі вивчення теоретичних дисциплін “Сольфеджіо”, "Гармонія", "Поліфонія", адже “студентимузиканти системно опановують музичне мистецтво через розуміння об' єктивних музичноісторичних процесів, набувають ерудованості, розширюючи коло знань музичних творів; навчаються орієнтуватися в історичній зумовленості музичних стилів; усвідомлюють і застосовують в інтерпретаційної діяльності принципи організації музичної мови, удосконалюють розуміння логіки музичної форми та іiі невід'ємність від змісту, що пов'язано з природою художнього образу в музиці, оволодівають навичками вербальної інтерпретації творів поряд з освоєнням музичної термінології' [4, 148-149].

Реалізація зазначеного принципу як основи формування поліфонічного мислення студентів вимагає створення спеціальних педагогічних умов. Цілеспрямоване педагогічне керівництво розвитком поліфонічного мислення студентів - перша педагогічна умова, що стала провідною в усьому комплексі представлених педагогічних умов. Така наша позиція зумовлена тим, що у контексті сучасних вимог до музичного виконавства сформованість музичного мислення виконавця набуває особливого значення.

Загальновизнаним $є$ той факт, що музичне сприймання безпосередньо пов'язане з музичнообразним мисленням, в результаті якого усвідомлюється й засвоюється музичний образ твору. Завдяки здатності музично мислити створюються узагальнені образи структурних одиниць творів, їх форм і жанрів. Це зумовлено тим, що уся фортепіанна музика різною мірою $є$ поліфонічною. Навіть гомофонія, в якій немає провідних голосів, а є тільки голоси, які доповнюють мелодію гармонічно, ритмічно, тембрально, виглядає багатошаровою побудовою. Своїм життям живе не тільки мелодія, а й бас і середні голоси. Виконавець усе це повинен не тільки знати, а й чути та відтворювати під час виконання. У процесі багаторазового сприймання поліфонічних творів закарбовуються не тільки конкретні музичні образи, а й утворюються узагальнені уявлення стосовно особливостей поліфонічного формоутворення, поліфонічності як властивості багатоголосся. У відпрацюванні таких еталонів й полягає специфіка формування поліфонічного мислення.

На думку 3. Рінкявічуса, “поліфонічне мислення музиканта дозволяє диференційованоцілісно уявляти одночасний розвиток деяких мелодичних ліній, музичних тем, а більш широко - і паралельний розвиток фактурних пластів з їхнім політональним, поліладовим, полігармонічним, поліритмічним, політембровим багатством тощо $[3,17]$. Вчений зазначав, що основою поліфонічного мислення є слухова перцепція, яка отримує звукову інформацію, а також значною мірою залежить від ретроспективної дії мислення $[3,18]$. Він підкреслював, що людина здатна не тільки чути, але й сприймати поліфонічну музику лише завдяки розвиненому поліфонічному мисленню. Для формування такого мислення, 


\section{ПРИНЦИП ОПОРИ НА ЄВРОПЕЙСЬКИЙ МУЗИЧНО-ІСТОРИЧНИЙ ДОСВД У ФОРМУВАННІ ПОЛІФОНІЧНОГО СЛУХУ СТУДЕНТІВ 3 КНР У ПРОЦЕСІ ФОРТЕПІАННОГО НАВЧАННЯ}

техніки виконання чудовою школою стає робота над поліфонією у іiі чистову вигляді.

Аналіз виконавської і педагогічної діяльності багатьох видатних музикантів доводить, що кожний з них мав поліфонічний склад мислення. Завдяки такому мисленню музикант органічно сприймає та відтворює архітектоніку музичних творів і розкриває їх образність. Так, Г. Нейгауз у роботі “Про мистецтво фортепіанної гри” [1] підкреслював: “ніщо так не виховує слух, звукову різноманітність, легато, пластичність як поліфонія". Видатний педагог уважав, що поліфонія належить до найважливіших засобів музичної композиції й художньої виразності. Розуміння виконавцем елементів музичної тканини на основі поліфонічного мислення набуває принципового значення і професійної функції у творчій діяльності музиканта. Художні досягнення видатних виконавців переконливо доводять, що високе володіння мистецтвом поліфонічної гри і в наш час залишається методом музичного мислення, наповненим смисловою значимістю та емоційної виразності.

Отже, робота над поліфонічною фактурою музичного твору ставить перед майбутнім учителем музичного мистецтва низку поліфункціональних завдань, які активізують його психічні процеси, зокрема такі як пізнання, абстрагування, розуміння основних виражальних особливостей поліфонічної мови. При цьому перед студентом відкривається широке поле для розвитку самосвідомості, здатності до самоконтролю, до оцінки себе, свого внутрішнього “я”, що створює умови для формування його мистецького світогляду [2].

У процесі розв'язання музичних творів на заняттях фортепіано майбутні вчителі музичного мистецтва системно опановують їх поліфонічну структуру через розуміння об'єктивних музичноісторичних процесів, набувають ерудованості в музичному мистецтві різних видів, стилів, жанрів тощо, розширюючи коло знання музичних творів; навчаються орієнтуватися в історичній зумовленості музичних стилів і жанрів; усвідомлюють і навчаються застосовувати під час аналітико-інтерпретаційної діяльності принципи організації музичної мови, удосконалюють власне розуміння музичної логіки формоутворення та її відповідність змісту, оволодівають навичками вербальної інтерпретації творів поряд з освоєнням музичної термінології.

У процесі вирішення цих завдань у майбутніх учителів музичного мистецтва активно розвивається емоційна сфера, здатність художньої емпатії та рефлексії, що становить основу для утворення особистісних художніх цінностей. У такий спосіб, саме на заняттях по фортепіано найбільше реалізується процес єдності власного поліфонічного мислення як художнього та абстрактно-логічного, наукового (теоретичного) мислення.

Відтак, стає очевидним, що формування поліфонічного мислення на заняттях по фортепіано розв'язують значною мірою й завдання музичносвітоглядного спрямування, завдяки зануренню у закономірності музичного мистецтва, розвитку поліфонічного сприймання для оволодіння музично-теоретичним матеріалом (його аналізу та узагальнення), засвоєння понятійного апарату, необхідного для інтерпретації музичних творів тощо.

Тому відповідно до першої педагогічної умови у процесі фортепіанного навчання формування поліфонічного мислення передбачає декілька аспектів, важливих для подальшого розроблення нашої методики:

- опанування музичних творів 3 насиченою поліфонічною фактурою та різних стильових напрямків;

- використання поліфонічної музики для того, аби протиставляти поліфонію і гомофонію як два виду музичної мови й, відповідно, як два типу музичного мислення, що проявляється у властивостях музичного матеріалу та закономірностях розвитку і побудови твору.

- занурення у цілісність музичних образів; врахування різних типів поліфонії - імітаційної, контрастної тощо; здійснення цілісного аналізу таких творів у зіставленні з виконавськими інтерпретаціями видатних піаністів, що ефективно впливає на розширення поліфонічного мислення майбутнього вчителя музичного мистецтва і тим самим збагачує його професійну підготовку;

- використання поліфонічних творів у різноманітних музичних ситуаціях, що ефективно спрямовує студентів на творчий пошук, пробуджує креативність, імпровізаційні здібності, здатність сприймати поліфонію як художнє явище в мистецтві.

Крім того, реалізація першої й основної педагогічної умови означає, що формування поліфонічного мислення майбутніми вчителями музичного мистецтва безпосередньо впливатиме на збагачення їх досвіду, набутого на інших фахових музичних дисциплінах, а саме:

- у напрямі удосконалення знань в курсі гармонії та цілісного аналізу музичних творів, спрямованих на майбутню музично-педагогічну творчість, що потім проявляється під час педагогічної практики;

- назаняттях з хорового диригування і хорового класу; 


\section{ПРИНЦИП ОПОРИ НА ЄВРОПЕЙСЬКИЙ МУЗИЧНО-ІСТОРИЧНИЙ ДОСВІД У ФОРМУВАНН}

ПОЛІФОНІЧНОГО СЛУХУ СТУДЕНТІВ З КНР У ПРОЦЕСІ ФОРТЕПІАННОГО НАВЧАННЯ

- у процесі ансамблевого музикування (інструментального, хорового);

- під час підготовки і виступу на концертах, що може позначатися на виконавській інтерпретації твору.

Таким чином, насиченість змісту музичного навчання поліфонічною фактурою і формування поліфонічного мислення впливає як на розширення музичного світогляду студентів, так й на розвиток їх музичної культури як основи оволодіння виконавськими і аналітико-інтерпретаційними навичками.

Друга педагогічна умова - стимулювання студентів до оволодіння уміннями поліфонічного виконання - націлена на розуміння поліфонічної мови, адже поліфонія висуває низку вимог до уваги виконавця і слухачів. По-перше - це гнучкість, рухливість і розподіл уваги. Без цього неможливо здійснювати ії майже безперервне переміщення 3 одного голосу на інший, які безперервно рухаються. По-друге - значний об'єм уваги, оскільки необхідно охоплювати чимало різнорідних мелодійних утворень, перебіг яких відбувається одночасно. Іноді тема та її протистояння можуть рухатися у різних напрямах, навіть у різному ритмі й не збігатися 3 опорними й акцентованими моментами. Буває, що різні голоси вимагають відтворення різними штрихами - одні легато, а інші стаккато. Важко також скоординувати звучання, коли один або декілька голосів зупиняються на одній ноті, а інші продовжують рухатися. Така складність виникає через різницю фортепіанного звучання у момент натискання клавіш і поступового зменшення його сили та яскравості. Натомість поліфонія вимагає, щоб кожний голос упродовж всього руху звучав рівно і зливався з іншими голосами.

Отже, перед виконавцем стоїть складне завдання - рельєфно відтворити кожний голос, узгодити різноманітну виразність i, водночас добитися їх єдності, аби вони утворювати єдиний ансамбль. Відтак, вчителю музичного мистецтва, як виконавцю, важливо враховувати всі ці особливості поліфонічної мови і бути готовим до виконання різних поліфонічних творів, адже поліфонія й в наш час залишається методом музичного мислення.

Висновок. Таким чином, обгрунтовуючи важливість i доцільність застосування вищерозглянутого принципу - вивчення вітчизняного і зарубіжного досвіду, - наголосимо, що цінність такого досвіду для практики фортепіанної підготовки українських і китайських студентів полягає у тому, що в його основі лежить навчально-педагогічна діяльність, у процесі якої використовуються оригінальні методи, форми, прийоми, засоби музичного навчання і виховання, нові освітні технології для забезпечення стабільних позитивних результатів у розв'язанні педагогічних і виконавських завдань.

\section{ЛІТЕРАТУРА}

1. Нейгауз Г. Об искусстве фортепианной игры. Москва : Музыка, 1987. 238 с.

2. Полатайко О., Сяо Лі. Діалектичний аспект формування поліфонічного мислення студентівмузикантів педагогічного профілю. Науковий часопис Національного педагогічного університету імені М.П.Драгоманова. Серія 14. Теорія методика мистецької освіти: зб. наук. праць. Київ: 2016. Вип. 20 (25). С. 28-34.

3. Ринкявичюс 3. Воспринимают ли дети полифонию? Ленинград: Музыка, 1979. 64 с

4. Ся Гаоян. Поліхудожня підготовка майбутнього вчителя музики: зміст, структура, орієнтири для діагностування. Молодь і ринок. Щомісячний науково-педагогічний журнал. Дрогобич, 2018. № 10 (165). С.147-151.

5. Фу Сяоцзін. Методика концертмейстерської підготовки майбутніх учителів музики України і Китаю : автореф. дис. на здоб. наук. ступ. канд. пед. наук 13.00.02. Київ, 2012. 20 с.

6. Шугуан Методика формування виконавського досвіду майбутніх учителів музики в процесі фортепіанної підготовки : дис. канд. пед. наук : 13. 00. 02. Київ, 2012.189 с.

\section{REFERENCES}

1. Neygauz, G. (1987). Ob iskusstve fortepiannoy igry [About the art of piano playing]. Moscow, $238 \mathrm{p}$. [in Russian].

2. Polataiko, O. \& Siao, Li (2016). Dialektychnyi aspekt formuvannia polifonichnoho myslennia studentiv-muzykantiv pedahohichnoho profiliu [Dialectical aspect of formation of students'musicians' polyphonic thinking in pedagogical profile]. Scientific journal of the Mykhaylo Drahomanov National Pedagogical University. Series 14. Theory and methods of art education: Coll. of Science. works. Kyiv, Vol. 20 (25). pp. 28-34. [in Ukrainian].

3. Rinkyavichyus, Z. (1979). Vosprinimayut li deti polifoniyu? [Do children perceive polyphony?]. Leningrad: Muzyka, 64 p. [in Russian].

4. Sia Haoian (2018). Polikhudozhnia pidhotovka maibutnoho vchytelia muzyky: zmist, struktura, oriientyry dlia diahnostuvannia [Polyartistic training of the future music teacher: content, structure, guidelines for diagnosis]. Youth and market. Drohobych. No. 10 (165).pp.147-151. [in Ukrainian]. 


\section{КУЛЬТУРНА КОМПЕТЕНТНІСТЬ ЯК РЕЗУЛЬТАТ ФАХОВОЇ ПІДГОТОВКИ ВЧИТЕЛІВ МУЗИЧНОГОМИСТЕЦТВА}

5. Fu Siaotszin (2012). Metodyka kontsertmeisterskoi pidhotovky maibutnikh uchyteliv muzyky Ukrainy i Kytaiu [Methods of concertmaster training of future music teachers of Ukraine and China]. Extended abstract of candidate's thesis. Kyiv, $20 \mathrm{p}$. [in Ukrainian].
6. Shuhuan (2012). Metodyka formuvannia vykonavskoho dosvidu maibutnikh uchyteliv muzyky $\mathrm{v}$ protsesi fortepiannoi pidhotovky [Methods of forming the performing experience of future music teachers in the process of piano training]. Candidate's thesis. Kyiv, 189 p. [in Ukrainian].

Стаття надійшла до редакції 28.04.2021

УДК 378.37.01:78

DOI:

Чжоу Тінтін, аспірантка факультету мистецтв імені Анатолія Авдієвського Національного педагогічного університету імені М. П. Драгоманова

\section{КУЛЬТУРНА КОМПЕТЕНТНІСТЬ ЯК РЕЗУЛЬТАТ ФАХОВОЇ ПІДГОТОВКИ ВЧИТЕЛІВ МУЗИЧНОГО МИСТЕЦТВА}

Аналізується феномен культурної компетентності вчителів музичного мистецтва. Подається уточнена сутність поняття на перетині дефініцій “компетентність” та “культура” Культурна компетентність у системі іниих базових та фахових компетентностей. Доведена системоутворювальна роль культурноі компетентності стосовно решти базових компетентностей, щуо не залежить від сфери професійної реалізачї суб 'єкта. Водночас показано, щчо культурна компетентність є інтегральною фаховою предметною в системі підготовки вчителів мистецьких дисциплін.

Ключові слова: учителі музичного мистецтва; культурна компетентність; ключові компетентності, циикли фахової музично-педагогічної підготовки.

Jim. 13.

Zhou Tingting, Postgraduate Student of Faculty of Arts named after Anatoliy Avdiyevskiy, Mykhaylo Drahomanov National Pedagogical University

\section{CULTURAL COMPETENCE AS A RESULT OF PROFESSIONAL TRAINING OF MUSIC TEACHERS}

Based on the study of scientific sources and international regulations, the phenomenon of cultural competence of music teachers is analysed. The essence of cultural competence at the intersection of the concepts "competence" and "culture" in aesthetic-philosophical and culturological perspectives is is specified. The training of a specialist is interpreted as mastering a set of key and cross-cutting and competencies, as well as professional ones. Cultural competence is considered as a key (basic) competence of a personality in the system of other basic competences defined at the European level. The interpretation of the content of cultural competence in the educational systems of Europe, first of all Ukraine, and China is compared. The leading means of formation of the person's cultural competence is art education and the process of artistic perception of the personality as a universal factor influencing the person's sensory sphere. The integral interdisciplinary and system-forming content of cultural competence in relation to other basic competences regulated by the legislation of different countries is proved. It is found that this role of the phenomenon does not depend on the scope of professionalpersonal realization. The essence of cultural competence is projected on mastering the content of all disciplines of professional training of future music teachers.

The cultural content of each cycle of disciplines of professional training of music teachers are the following. music-performing, music-methodical.

It is shown that cultural competence also plays an integral role in the system of training teachers of art disciplines, it is a professional competence. Its content reflects the training of a specialist as a musician and at the same time in the projection of multifaceted pedagogical activities. training

Keywords: music teachers; cultural competence; key competences; cycles of professional music-pedagogical

П

остановка проблеми. Вимоги до високого рівня якості освіти зумовлюють увагу до сформованості комплексу компетентностей у випускників закладів педагогічної освіти - фахових, зокрема предметних, та життєвих (базових, ключових).
Припускаємо, що в цій системі інтегральну роль виконує компетентність культурна, яка охоплює зміст інших компетентностей і водночас спирається на них. У формуванні культурної компетентності провідну роль відіграє мистецька освіта, провідним засобом якої є художнє пізнання, 